\title{
The Implementation of The n-term Formula to Improve Student Ability in Determining the Rules of a Numeric Sequence
}

\author{
Akhsanul In'am ${ }^{1} \&$ Siti Hajar ${ }^{2}$ \\ ${ }^{1}$ Mathematics Department University of Muhammadiyah, Malang, Indonesia \\ ${ }^{2}$ State Islamic Junior High School, Malang, Indonesia \\ Correspondence: Akhsanul In'am, Mathematics Department University of Muhammadiyah Malang Jln. Raya \\ Tlogomas No 246, Malang, Indonesia. Tel: 62-812-321-6030. E-mail: ahsanul_in@yahoo.com
}

Received: February 4, 2013

Accepted: February 25, 2013

Online Published: March 7, 2013

doi:10.5539/ies.v6n4p67

URL: http://dx.doi.org/10.5539/ies.v6n4p67

\begin{abstract}
A good-quality teacher may determines a good-quality learning, thus good-quality students will be the results. In order to have a good-quality learning, a lot of strategies and methods can be adopted. The objective of this research is to improve students' ability in determining the rules of a numeric sequence and analysing the effectiveness of the implementation of the $n$-term to determine the rule of a number. A research classroom method administered at the State Islamic Junior High School Malang-Indonesia is adopted. The results show that the implementation of the $n$ term formula may improve the students' ability in determining the numeric sequence in the State Islamic Junior High School Malang-Indonesia. Some suggestions are offered: a) observation of learning activities should always be made to obtain inputs on the implementation; b) learning innovations should always be made to base on facts obtained through observation; c) the results of this study may be used for reference for further development in learning numeric sequences that enable students to be more interested in studying mathematics.
\end{abstract}

Keywords: good-quality learning, numerical sequence, the $n$ term formula

\section{Introduction}

Each learning approach may be used as teacher guide in designing learning activities as efforts to help students attain their learning objectives. The learning approach is a systematic procedure as a teacher guide in designing their learning activities to reach their predetermined learning objectives (Sakdiyah, 2006; Utomo, 2007; Nurdin, 2007).

A learning strategy adopted cannot be said to the best strategy for all learning materials, but for a certain material. (Arends, 1997; Noraini, 2005). In determining an appropriate strategy, it is the teacher who determines, since he is a very important part in the learning activities and the main factor in the process of improving the quality of education (Fasli \& Dedi, 2001; Sakdiyah, 2006), besides, students, curriculum, facilities and infrastructure factors (Bafadal, 2004; In'am, 2012). A teacher is a human element that heavily determines the success of education that is why it can be stated that the improvement of school quality is dependent upon teacher professionalism (Bafadal, 2004; In'am, 2012). A good-quality teacher may commit a quality learning, implying that good-quality students will be the result (Wahyudin, 2007; In'am, 2012), and to reach such a quality learning, a lot of strategies and approached may be adopted.

There are various factors influencing the success in learning mathematics. A successful teacher of mathematics should be able to cope with and to solve any learning problems in the class intelligently (Nik Aziz, 2008; I Made, 2008). There are some matters to pay attention in mathematics learning namely: a) students are actively involved in their learning and are learning mathematics meaningfully accompanied with working and thinking and doing their learning to learn; b) any new information should be related to other information, so that it will unite into a scheme students possess to make any comprehension of complex information happen; c) learning is oriented into investigation and discovery which is principally problem solving in nature (Hudoyo, 2005; Noraini, 2005).

On the basis of observation the researchers have made, students are often difficult to determine the $n$ term formula from the numerical sequence with certain patterns. The patterns and rules prevailed between one 
numerical sequence and another might be different, since the numerical sequence cannot be categorized into an arithmetic sequence.

From the description above, it is necessary to change the implementation of the learning activities and to make researches in order to solve the problem. Therefore, the following two research questions were addressed in this study:

1) How is the implementation of the n-term forluma to improve the ability in determining the rule of numeric sequence of the students in State Islamic Junior High School Malang-Indonesia?

2) How is the effectiveness of the implementation of the n-term formula to determine the rule of the numeric sequence of the students in State Islamic Junior High School Malang-Indonesia?

\section{Review of Literature}

Mathematics is one of subjects taught in almost each type and level of education, from elementary up to higher education levels, either in general or vocational education. According to the curriculum of elementary and secondary schools, the form of the mathematics is a school mathematics, of which its elements are chosen in terms of education interest and development of science and technology (Soedjadi, 2000). The presentation of objects in mathematics should not start from definition or theorem, but adjusted to the student intellectual development. It is that differentiates between school mathematics and mathematics as a science (Soedjadi, 2000).

\subsection{Learning of Mathematics}

Any effort made to develop any learning is always intended to improve the quality of student comprehension about the materials (Jerome, 2005; In'am, Saad \& Ghani, 2012). This also happens in the learning mathematics and the development of curriculum is still needed. There are four main questions to develop the curriculum of mathematics: a) why is mathematics taught?; b) what is taught?; c) how to teach mathematics and d) to whom is it taught? (Hudoyo, 2005).

\subsection{Factors Improving the Quality of Mathematics Learning}

Something which is really relied on to improve the quality of education at schools are teacher professionalization, mastery of materials, and wide insights that serve as a stepping stone into professional teachers (In'am, 2010). A teacher is formally born by a teacher training and education institution (Fasli \& Dedi, 2001). As an institution working in producing teachers automatically has various qualities due to various factors influencing the process of education. As a consequence, teachers produced also vary in quality. Such various qualities will produce diverse results, and this could be studied and investigated in order to find the best solution.

The mastery of materials is a must for teachers, and they should always enrich and improve their teaching materials which are directly or indirectly taught to their students. Dealing with the presentations of the materials, teachers should pay attention to where, when and to whom the materials are given. If teachers really master their materials, the materials taught will be relatively easy to be understood by students, but if this mastery is ignored, students will not maximum understand the materials, and this condition will result in low quality students. It is which is called understanding of student characteristics.

Dealing with the teaching style, either concerning with the way of starting teaching, speaking, writing on the board or of dressing really influence students' comprehension of the materials. A teacher with sad face, for instance, will make students difficult to understand the material he teaches. Therefore, a teacher should try to show their top performance by showing their enthusiasm and bright smile, sincerity, willingness to guide, to motivate, and to lead students so that students may understand and comprehend the materials taught.

Not every teacher is capable of conveying ideas well. Some teachers, especially those teaching exact sciences, have hindrances in communication, and it is not the case of those teaching social sciences. However teachers should be capable in extending ideas and this capability can be improved by continuous trainings, although this capability has been trained during their teacher training and education.

The extend to which students master the materials should be capably measured by teachers. Such a measurement can show to the teacher whether his/her teaching style can be accepted by students, whether the material is too difficult for students, whether the time allotted to the material is enough, and the like.

Choosing teaching profession, teachers should always try to improve their capabilities in the their profession by renewing their knowledge in order to be able to follow the development of the subjects they teach, to understand the development of their students' social condition, to improve their expertise in conveying their learning materials to make their students understand them. 


\subsection{Creativity in Mathematics Learning}

One of objectives in doing an activity is to find out meanings from something being done. It is also the case in the thinking process, namely to attain meaning. John Dewey in Azizi (2005) defines that thinking is an operation making use of the existing facts in order to design other new facts that can be believed based on the existing facts, meanwhile Chaffe (1991) in Azizi (2005) defines that thinking is an extraordinary process used in the decision making and problem solving processes.

A thinking activity involves three components: mental operation, knowledge and attitude. Thinking consists of mental activities, namely an operation made by the brain. Cognitive operation is used to find out the existing meaning, and it consists of two components namely skillfulness and process. A skillfulness is special and brief such as a processing skillfulness that functions to analyze and to synthesize, and thinking is critical and creative, meanwhile process or strategy is complex, such as in decision making and problem solving (Noraini, 2005).

A cognitive operation comprises an operation that lead and guide skillfulness and cognitive process, meta-cognition is usually known as the thinking about thinking itself, realizing about what is known and anything that is not understood (In'am, 2012).

Dealing with the numerical sequence learning, to make students have critical and creative thinking, teachers should lead the process. This will help students solve problems by making relevant and appropriate decisions. What teachers can do to bring about students' creativity and criticality to solve numerical sequence problems is to introduce and to explain an arithmetic sequence as materials to comprehend a rule of numerical sequence.

\section{Methodology}

\subsection{Research Design and Setting}

It is a classroom action reserach intended to implement the n-term formula in order to improve the students' abilities in determining the rules of numeric sequence. This classroom action research consisted of two cycles, first is a preliminary reflection on the learning activities that had been done, then planning was made and continued into action, and reflection was made in order to make a plan used to do the second cycle.

\subsection{Participants}

This research was the ninth grade students of The State Islamic Junior High School Malang-Indonesia, consisting of 25 students, 12 boys, and 13 girls. On the basis of the observation the researcher made during the learning activities, preliminary data were obtain that students often had difficulties in determining the $n$ term formula of a numerical sequence.

\subsection{Instrument}

The instruments used to obtain the data were the learning implementation monitoring and learning achievement tests to see the students' learning results before and after the learning implementation.

The evaluation of the validity of the learning implementation monitoring instrument was made by two experts and 3.5 scores were obtained, and on the basis of the criteria of the instrument validity, if the average score is higher that 3, it can be stated that the instrument meets the validity. So that it can be stated that the instrument fulfils the requirement of validity. Meanwhile to understand the realibility of the instrument, two persons watched the implementation and in this matter Grinnell's (1988) agreement percentage formula was adopted and the reliability coefficient of $R=0.85$ was obtained and this shows that $R>0.75$, meaning that this instrument meets of reliability.

The validity test of the learning results was made through a try-out intended to obtain an item validity namely the extent of the support of each item to the whole score by counting the correlation between the items score and the whole score, while the reliability of the instrument was analysed by using the correlation evaluation $r$ using the split-half method (Suharsimi, 2009). On the basis of try-out result, the $r$ values were $0.78 ; 0.74 ; 0.63 ; 0.87$ and 0.68 , and it can be stated that the evaluation tes of the learning results met the validity, meanwhile the internal consistency reliability of the scale (Cronbach alpha) was 0.79 .

\subsection{Data Collection, Procedure and Analysis}

The data were the results of student learning before and after actions and to obtain the data, a comprehension test was administrated. The collected data were in the form of the final grades from the first and the second cycles. To solve the problems, the researcher tried to do learning activities emphasizing the use of the $n$ term formula of an arithmetic numerical sequence to facilitate the student comprehension in an effort to find out the formula. 
The implementation of action consists of four stages namely, planning, action, observation and reflection with its activities of each stage as shown in Table 1.

Table 1. The plan of action and its implementation

\begin{tabular}{ll}
\hline Stages & Activities \\
\hline $\begin{array}{l}\text { Planning (problem } \\
\text { identification and the } \\
\text { determination of problem } \\
\text { solving alternatives) }\end{array}$ & $\begin{array}{l}\text { Deternining the } n \text {-term formula from the numerical sequence will be determined } \\
\text { by trial and error as stated in the student worksheet. But in fact students have } \\
\text { various difficulties in looking for the } n \text {-term formula from a numerical sequence. }\end{array}$ \\
$\begin{array}{l}\text { Action } \\
\text { Observation }\end{array}$ & $\begin{array}{l}\text { Discovering the } n \text {-term formula will be made by trial and error by paying } \\
\text { attention to the characteristics of a numerical sequence. } \\
\text { The focus of the observation will be on the determination of } \text { the } n \text {-term formula }\end{array}$ \\
Reflection & $\begin{array}{l}\text { The results of the observation will be analyzed to obtain the picture on the } \\
\text { impacts from the action made and anything to do for the next action. }\end{array}$ \\
\hline
\end{tabular}

The analysis made was the guide of individual grades based on student mastery in terms of two things as follows: a) individual students are said to be successful in achieving the predetermined mastery if they reach minimum mastery level of $80 \%$ or scores of 75 ; b) students are said to master the numerical sequence if $80 \%$ students reach $75 \%$ of the predetermined evaluation aspect.

\section{Results}

This research activity was made in two cycles, where each consisted of four activities, namely planning, action, observation and reflection. The success in the implementation of this research is determined by a certain criterion namely mastery learning.

\subsection{The Implementation of the Use of the N-Term Formula in Learning}

The learning implementation consisted of two cycles with which each cycle was made four stages as follows.

\subsubsection{The First Cycle}

As previously said, each cycle consists of four stages namely planning, implementation, observation and reflection.

The first activity is planning, which is intended to plan the learning implementation, where standard of competence and basic competence students should master should be paid attention. The chosen standard of competence in this present study is to comprehend the numerical sequence and series and their uses to solve problems and the basic competence is to determine patterns of simple numerical sequence. Based on the basic competence, students should master the attainment indicators, namely: a) stating everyday problems related to numerical sequence; b) being familiar with elements of numerical sequence and series; and c) determining the $n$ term formula.

On the basis of the planning in the learning implementation, the teachers started his learning activities with apperception through recalling the numerical sequence. By sharing with students, the depth of their mastery of the numerical sequence was known.

The next activity is to learn the numerical sequence through dialogues. To help students comprehend the sequence, the teacher made use of marbles to demonstrate the numerical sequence. And as the last stage, students did exercises under the teacher guidance.

The next activity is the observation the teacher made with the help from a observation team where the duty is to observe the learning activities. The observation started from the beginning of the learning activity, namely apperception, to the students doing exercises. At this state, there were few students who were interested in learning mathematics, seen from their participation and from their questions they asked. They were also reluctant to do exercises of which the number of the exercises was relatively high.

From the observation, the scores the students obtained were less satisfactory and from responses to the four questions from the observation instrument, it seemed that most students were not interested in asking and 
answering them yet and in the learning materials. Moreover there were also many students who were reluctant to do the exercises. Therefore, he teacher decided to continue the study by improving the plan in the learning implementation.

\subsubsection{The Second Cycle}

In order to improve the quality of learning in the first cycle, the second cycle was done with the same stages as in the first cycle.

The plan in the second cycle was made by improving the design of learning implementation based on the results of the observation activities in the reflection. The improvement made is in making a plan in learning the numerical sequence and series making use of arithmetic sequence in order to determine the rule of the numerical sequence which is different with that of arithmetic sequence. This also occurred in the second stage.

On the basis of the plan in the learning implementation which were improved based on the observation and reflection in the first cycle, the learning activity began with the apperception, namely discussing the homework, and recalling the elements of the sequence and series.

Then, the students were grouped into some groups to discuss the sequence and series and their elements namely the first term, the second term, the $\mathrm{n}$ tem, difference and ratio. The next is that students discussed the $\mathrm{n}$ term formula and to share the results of their group discussion with other groups. After talking about various things on sequences and their elements, students did exercises dealing with the numerical sequence.

The teacher, as in the first cycle, with the help of an observer, observed the condition of the learning activity. On the basis of the observation instrument, in the implementation of the learning activities in the second cycle, the results of observation showed that: a) the student participation in learning was relatively good; b) the students showed a good enthusiasm in the discussion as seen in the question-answer activities, this due to the fact that the way the teacher explained how to obtained the $\mathrm{n}$ term rule from a numerical sequence different from the arithmetic sequence is more easily understood than the trial-and-error mode made so far; c) students were more interested in learning the sequence and the series; and d) the students were more happy with learning the material of the numerical sequence.

From the results of the observation, it can be reflected that in the learning activities, innovations should always be made as in learning the sequence. The students felt that they were easy to learn the sequence and series, especially from the application of the $\mathrm{n}$ term formula of an arithmetic sequence into the numerical sequence with differential $(b)$ as in the arithmetic sequence and the numerical sequence with differential $(b)$ as in the second cycle.

From the results of the second cycle, it can said that the learning design would not be continued into the next cycle, since the results of the observation and tests showed satisfactory condition and achievement.

The implementation of the classroom action research in the two cycles show satisfactory results either viewed from the results of observation or the results of the tests made at the ends of the first and second cycles. The following will be presented the results of observation and tests:

\subsubsection{Observation of the Implementation if Learning Activities}

Observations in the learning activities were made by the teacher with the help colleagues using the observation instruments. The results of the observation of the implementation of the learning activities during the two cycles consisting of four sessions are presented in Table 2.

Table 2. Observation of the learning activities

\begin{tabular}{lcccc}
\hline \multirow{2}{*}{ Student Activities } & \multicolumn{2}{c}{ Cycle-1 (f/\%) } & \multicolumn{2}{c}{ Cycle-2 (f/\%) } \\
\cline { 2 - 5 } & 1 & 2 & 1 & 2 \\
\hline Student participation in asking questions & $6(24 \%)$ & $8(32 \%)$ & $15(60 \%)$ & $20(80 \%)$ \\
Student participation in giving answers & $7(28 \%)$ & $8(32 \%)$ & $14(56 \%)$ & $19(76 \%)$ \\
Student interest in the learning materials & $8(32 \%)$ & $6(24 \%)$ & $17(68 \%)$ & $21(84 \%)$ \\
Student enthusiasm to do tests & $5(20 \%)$ & $9(36 \%)$ & $13(52 \%)$ & $15(60 \%)$ \\
\hline
\end{tabular}

Table 2 shows that student participation to ask and to answer questions increased from the cycle 1 to the cycle 2 from $24 \%$ to $80 \%$. It shows that the way teacher taught the sequence by applying the rules of arithmetic 
sequence makes students like to participate, either to ask and to answer questions, and to study the learning materials with a meaningful increase. Moreover, the student enthusiasm to do exercises also increases significantly. In the cycle 1, there were 20 students who show such an enthusiasm, but this increases $60 \%$ at the end of cycle two.

Student interest in the learning materials at the end of the cycle 2 occupies the highest rank from the four questions in the observation instrument with the frequency and percentage of $21(84 \%)$, meanwhile the student enthusiasm, 15(60\%).

Student participation in answering questions shows the least frequency than the other three, but this difference is not meaningful. This means that the four questions shows that there is a meaningful increase from the movement in the first meeting of the first cycle to the second meeting of the second cycle.

The results show that at the second cycle, the students are more interested in learning mathematics using an approach to searching the $n$ term formula of the arithmetic sequence applied in the numerical sequence with a differential $(b)$.

\subsection{The Effectivenes of the Use of the N-Term Formula in Learning}

To understand a success in learning and in the mastery of learning materials, tests are needed. From the results of observation, in the first and second meeting, students were reluctant to do exercises, but in the third and fourth meetings, most students were not reluctant anymore to do exercises. They were happy with going the exercises, and this implies for doing tests at the end of the cycle.

Table 3. The comparison of the test results of the first and second cycles

\begin{tabular}{ccccc}
\hline Student & $\begin{array}{c}\text { Score of Mathematics Test of } \\
\text { Cycle- } 1\end{array}$ & $\begin{array}{c}\text { Score of Mathematics Test of } \\
\text { Cycle- } 2\end{array}$ & Increase & $\%$ \\
\hline 1. & 80 & 90 & 10 & 12.5 \\
2. & 80 & 100 & 20 & 25.0 \\
3. & 65 & 100 & 35 & 53.8 \\
4. & 80 & 100 & 20 & 25.0 \\
5. & 70 & 90 & 20 & 28.6 \\
6. & 60 & 85 & 15 & 25.0 \\
7. & 60 & 80 & 20 & 30.0 \\
8. & 65 & 100 & 35 & 53.8 \\
9. & 85 & 100 & 15 & 17.6 \\
10. & 60 & 70 & 10 & 16.7 \\
11. & 60 & 100 & 40 & 66.7 \\
12. & 80 & 100 & 20 & 25.0 \\
13. & 65 & 75 & 10 & 15.4 \\
14. & 55 & 65 & 10 & 18.2 \\
15. & 65 & 100 & 35 & 53.8 \\
16. & 65 & 80 & 15 & 23.1 \\
17. & 80 & 85 & 5 & 6.3 \\
18. & 80 & 100 & 20 & 25.0 \\
19. & 65 & 75 & 10 & 15.4 \\
20. & 80 & 100 & 20 & 25.0 \\
21. & 80 & 100 & 20 & 25.0 \\
22. & 65 & 80 & 25 & 38.5 \\
23. & 65 & 75 & 10 & 15.4 \\
24. & 75 & 90 & 15 & 20.0 \\
25. & 65 & 95 & 30 & 46.2 \\
\hline
\end{tabular}

The results of the tests administrated at the end of the first and second cycles showed a meaningful increase. No students showed any decrease and the percentage in the increase is from $5.3 \%$ to $66.7 \%$, with the average in increase of $28.28 \%$, and this shows that all students show an increase in score. Those shows a low increase in percentage is due to the fact that their scores at the end of the first cycle are relatively high, whereas those with a 
relatively high increase are caused by their low scores in the first cycle and they then show meaningful increases at the end of the second cycle.

Some criteria are adopted to determine the learning mastery: a) an individual student is said to be successful in attaining indicators of the determined mastery if he/she at least reaches a level of mastery of minimum $80 \%$ or she/he gets a minimal grade of 75 ; b) Students are said to have mastered the learning of the numerical sequence if $80 \%$ of all students have attained $75 \%$ of the evaluation aspect that has been determined before.

\section{Discussion}

The implementation of the n-term formula to determine a numerical sequence may improve the students' abilities in determining the numerical sequence in learning an arithmetics. The results of study showed that the tests done in the cycle 1 and 2 showed that there is some increase. But it can be stated that the implementation of learning in the first cycle had not met the criteria so that the second cycle should be done. The teacher got an idea to continue into the second cycle due to the fact that the students still had difficulties in determining the $n$-term formula by trial and error. It is in line with the statement may by Joyce, Bruce \& Weil (2009), that a learning model is a design that may be used to design and to lead learning activities. Meanwhile Eggen \& Kauchack (2009) say that a learning model is a perspective on learning designed to attain certain learning objectives.

Seeing the importance of studying and building a learning model giving priority on students as a center for the learning implementation and reducing the teacher roles, may experts trying to build learning models may lead and motivate students to be more innovative and creative in their learning activities. Sakdiyah (2006) developed a learning model on numbers for seventh grade students using the constructivist principle. Nurdin (2007) employed this principle, and also Utomo (2007) in primary schools.

Another research showed that in order to attain educational objectives, there are some factors considered namely students, curriculum, facilities and infrastructures and teachers (Abd Rahim, 2005; Bafadal, 2004), and a teacher is the main factors in the educational process and is an important part of learning (Bafadal, 2004; Fasli \& Dedi, 2001). Therefore, teachers should always make some innovations and creativities in their learning activities. High quality teachers may make high quality learning activities, implying that high quality students are the results, and it means that a high quality education will be resulted.

A high quality teacher is one aspect of the implementation of professionalism in doing a his/her job, therefore, some improvements should be made through a reform in education while paying attention to the teaching and learning concepts on how teachers and students should do their learning activities (Brook \& Brook, 1993; Wina, 2008). The reform in education means any efforts to create programs focused on the improvement in learning qualities, so that the learning activities are really those for solving failures students face in learning.

Dealing with mathematics, there are many studies showing that materials in mathematics are those with high percentage of potential failures and with the medium achievement among the majority students (Saad, 2004). The results are in line with the concern among scholars in mathematics with students' problems in solving mathematics problems, but most educatiors realize that students have difficulties in solding mathematics problems (Saad, 2004). Solbing a mathematics problems is an abstract and complicated process and involves human thinking and thinking prower. (National Council of Teachers of Mathematics [NCTM],2000).

Some other studies showed that any difficulties in and approaches to algebra are always caused by arithmetic learnings focused on the algebraic decision process compared with a structured aspect. Learning algebra emphasizes various situations (Sfard, 1995). Some studies in the field of algebra are based on the problem solving dealing with strategies and concepts where teachers should make more effective learning activities in the classrooms (Saad, 2004).

From the descriptions above, it is shown that the study in this research gives some additional knowledge and also innovations and creativities in the implementation of learning mathematics, especies in arithmetics, so that it may improve the students' comprehension on the materials their learn.

\section{Conclusion}

On the basis of the analysis and interpretation, it can be concluded that:

1) The implementation of the $n$ term formula to determine a numerical sequence consisiting of four aspects improves in either the cycle- 1 or cycle- 2 as summarized: a) the average percentage of student participation in asking questions increased from $28 \%$ in the cycle- 1 into $70 \%$ in the cycle-2; b) the average percentage of students in answering questions increased from $30 \%$ in the cycle-1 into $76 \%$ in the cycle- 2 ; c) the average 
percentage of student interest in the learning materials increased from $28 \%$ in the cycle- 1 becoming $76 \%$ in the cycle -2 and d) the average percentage of student enthusiasm in doing problems increased from $38 \%$ in the cycle-1 becoming $56 \%$ in the cycle- 2 .

2) The implementation of the $n$ term formula to determine the numerical sequence was very effective and it is shown by the test results made on the cycle-1 to the cycle- 2 that showed an improvement. The percentage of the increase was from $6.3 \%$ to $66.7 \%$ with the average increase of $28.28 \%$.

From the results of this research, some suggestions are offered: a) the learning activities should always be observed in order to get inputs to the implementation; b) learning innovations should always be made on the basis of the facts obtained through observations made; c) the results of this research can be made as a reference to make further development in learning the numerical sequence that enables students to be more interested in learning.

\section{References}

Abd Rahim, A. R. (2005). Profesionalisme Keguruan Prospek dan Cabarannya. Kuala Lumpur: Dewan Bahasa dan Pustaka.

Arens, R. (1997). Classroom Instructional Management. New York: Mc Graw Hill.

Azizi, Y., Noordin, Y., \& Zurihanmi, Z. (2005). Psikologi Kognitif, Johor: Universiti Teknologi Malaysia.

Bafadal, I. (2004). Peningkatan Profesionalisme Guru Sekolah Dasar. Jakarta: Bumi Aksara.

Brooks, J. G., \& Brooks, M. G. (1993). In Search of Understanding: The Case for Constructivist Classrooms. Virginia: Association for Supervision and Curriculum Development.

Dedi, S. (2003). Guru di Indonesia, Pendidikan, Pelatihan dan Perjuangannya sejak Zaman Kolonial hingga Reformasi. Jakarta: Departemen Pendidikan Nasional Dirjen Dikdasmen Direktorat Tenaga Kependidikan.

Eggen, \& Kauchak. (2009). Methods of Teaching: Promoting Students Learning in K-12 Classrooms. New Jersey USA: Pearson Education, Inc, Publishing as Allyn \& Bacon.

Fasli, J., \& Dedi, S. (2001). Reformasi Pendidikan dalam Konteks Autonomi Daerah. Yogyakarta: Adi Cita Karya Nusa

Grinnell, \& Richard, M. (1988). Social Work Research and Evaluation. Springfield: F. E. Peacock Publishers, Inc.

Hudoyo, H. (2005). Kapita Selekta Pembelajaran Matematika. Malang: UM Press.

I Made A. (2008). Peningkatan kualitas belajar siswa melalui pengembangan pembelajaran matematika berorientasi gaya kognitif dan berwawasan konstruktivis. Jurnal Penelitian dan Pengembangan Pendidikan, l(1), 1-14.

In'am, A. (2010). Pelaksanaan Pemerkasaan Guru Sekolah Menengah Pertama Negeri di Malang Indonesia. Tesis Ph.D Universiti Malaya Tidak dipublikasikan.

In'am, A., Saad, N., \& Ghani, S. A. (2012). A Metacognitive Approach to Solving Algebra Problems. International Journal of Independent Research and Studies, 1(4), 162-173.

Jerome, S. A. (2005). Pendidikan Berbasis Mutu, Prinsip-Prinsip Perumusan dan Tata Langkah Penerapan. Yogyakarta: Pustaka Pelajar.

Joyce, Bruce, \& Weil. (2009). Models of Teaching. New Jersey: Pearson Education, Inc, Publishing as Allyn \& Bacon。

National Council of Teachers of Mathematics. (2000). Principles and standards for school mathematics. Reston, VA: NCTM.

Nik Aziz Nik Pa. (2008). Isu-isu Kritikal dalam Pendidikan Matematik. Kuala lumpur: Penerbit Universiti Malaya.

Noraini, I. (2005). Pedagogi dalam Pendidikan Matematik. Kuala Lumpur: Utusan Stations \& Distributor Sdn. Bhd.

Nurdin. (2007). Model Pembelajaran Matematika untuk Menumbuhkan Kemampuan Metakognitif (Model $P M K M)$. Disertasi S-3 Pendidikan Matematika tidak dipublikasikan, Universitas Negeri Surabaya. 
Saad N. et al. (2004). Perlakuann Metakognitif Pelajar Tingkatan empat Aliran Sains dalam Penyelesaian Masalah Matematik Tambahan. Kajian Jabatan Matematik tidak dipublikasikan, Fakulti Sains dan Teknologi Universiti Pendidikan Sultan Idris.

Sakdiyah, C. (2006). Pengembangan Model Pengajaran dan Pembelajaran Matematik beracuan Konstruktivisme untuk Siswa SMP. Disertasi S-3 Pendidikan Matematika tidak dipublikasikan, Universitas Negeri Surabaya.

Sfard, A. (1995). The Development of Algebra: Confronting Historical and Psychological Perspectives. Journal of Mathematics Behaviour, 14, 18-39.

Soedjadi. (2000). Kiat Pendidikan Matematika di Indonesia, Konstatasi Keadaan Masa Kini menuju Harapan Masa Depan. Jakarta: Depdiknas.

Suharsimi, A, dkk. (2009). Penelitian Tindakan Kelas. Jakarta: PT Bumi Akara.

Utomo, D. P. (2007). Pengembangan Model Pembelajaran Kooperatif Matematika yang Berorientasi pada Kepribadian Siswa (Model PKBK) di Sekolah Dasar Disertasi S-3 Pendidikan Matematika tidak dipublikasikan, Universitas Negeri Surabaya.

Wahyudin. (2007). Strategi Belajar Mengajar Matematika. Bandung: UPI.

Wina, S. (2008). Pembelajaran dalam Implementasi Kurikulum Berbasis Kompetensi. Jakarta: Kencana Prenada Media Group. 